\title{
MATK wt Allele
}

National Cancer Institute

\section{Source}

National Cancer Institute. MATK wt Allele. NCI Thesaurus. Code C51090.

Human MATK wild-type allele is located in the vicinity of $19 p 13.3$ and is approximately 24

$\mathrm{kb}$ in length. This allele, which encodes megakaryocyte-associated tyrosine-protein

kinase protein, plays a role in the inactivation of Src-family kinases. 